\title{
STRATEGI KOMUNIKASI POLITIK TIM PEMENANGAN FACHRORI- SYAFRIL PADA PILKADA 2020 DI PROVINSI JAMBI
}

\author{
Ega Indiana $^{1}$, Irzal Anderson ${ }^{2}$, Dona Sariani ${ }^{3}$ \\ ${ }^{1,2,3}$ Pendidikan Pancasila dan Kewarganegaraan, Universitas Jambi \\ Jl. Jambi-Muara Bulian, Jambi Luar Kota, Muaro Jambi, Jambi 36361 \\ ${ }^{1}$ Email: egaindiana18@gmail.com \\ ${ }^{2}$ Email: irzalanderson@gmail.com \\ ${ }^{3}$ Email: donasariani@unja.ac.id
}

\begin{abstract}
ABSTRAK
Penelitian ini bertujuan untuk mengetahui strategi komunikasi politik tim pemenangan, kelebihan dan kelemahan serta penyebab rendahnya perolehan suara Fachrori-Syafril pada Pilkada serentak 2020 di Provinsi Jambi. Metode yang digunakan dalam penelitian ini adalah metode penelitian kualitatif yang lebih menekankan pada aspek secara mendalam terhadap suatu masalah. Hasil Penelitian ini menunjukkan bahwa strategi komunikasi politik yang digunakan oleh tim pemenangan Fachrori-Syafril masih terdapat masalah dan kendala sehingga menyebabkan rendahnya perolehan suara pasangan calon nomor urut 02 Fachrori-Syafril pada Pilkada Serentak 2020 di Provinsi Jambi. Hal ini dikarenakan faktor kampanye yang terbatas, orang baru dalam ranah politik, manajemen kandidat tidak berjalan serta faktor kekecewaan dari masyarakat.
\end{abstract}

Kata Kunci: Komunikasi politik, tim pemenangan, pilkada.

\begin{abstract}
This study aims to determine the political communication strategy of the winning team, the strengths and weaknesses as well as the causes of the low vote acquisition of Fachrori-Syafril in the 2020 simultaneous regional elections in Jambi Province. The method used in this study is a qualitative research method which emphasizes the in-depth aspects of a problem. The results of this study indicate that the political communication strategy used by the Fachrori-Syafril winning team still has problems and obstacles that cause the low vote acquisition for candidate pair number 02 Fachrori-Syafril in the 2020 Simultaneous Regional Head Elections in Jambi Province. This is due to limited campaign factors, new people in the political realm, candidate management does not work and the disappointment factor from the community.
\end{abstract}

Keywords: Political communication, winning team, pilkada.

\section{PENDAHULUAN}

Provinsi Jambi merupakan salah satu provinsi yang melaksanakan pesta demokrasi lima tahunan untuk memilih pemimpin baru yaitu Pemilihan Kepala Daerah secara serentak tahun 2020 di masa pandemi Covid-19. Menurut Peraturan Pemerintah Pengganti Undang-Undang Nomor 2 Tahun 2020 tentang Pemilihan Kepala Daerah (Perppu Pilkada) yang dikeluarkan oleh pemerintah untuk menggeser waktu pelaksanaan Pilkada 2020 dari semula tanggal 23 September menjadi 9 Desember 2020 akibat menyebarnya pandemi Covid-19. Dalam Perppu Pilkada tersebut seluruh tahapan pilkada wajib mengikuti sesuai 
dengan protokol kesehatan Covid-19. Begitupula dalam pelaksanaan pemilihan Kepala Daerah di Kota Jambi serentak tahun 2020.

Pemilihan Kepala Daerah di Provinsi Jambi tahun 2020 memunculkan tiga pasangan calon Gubernur dan Wakil Gubernur Jambi. Tiap pasangan calon memiliki sebuah tim pendukung yang bertugas untuk mencari massa pemilih dengan menggunakan strategi yang berbeda-beda dari tiap-tiap pendukung. Tim pendukung ini umumnya disebut sebagai tim sukses atau tim pemenangan dalam kampanye yang memiliki sejumlah anggota yang bertugas baik di lapangan maupun di posko tim pemenangan.

Salah satu rangkaian kegiatan dalam pelaksanaan Pilkada adalah kampanye politik. Kampanye politik merupakan sebuah bentuk komunikasi politik yang terorganisasi dalam waktu tertentu. Kampanye politik dapat dilakukan oleh seorang atau sekelompok orang atau organisasi politik untuk memperoleh dukungan politik dari rakyat (Cangara, 2011: 152). Kampanye yang dilakukan dalam rangka pemilihan kepala daerah pada hakikatnya adalah proses komunikasi politik, yakni segala bentuk aktivitas komunikasi yang dilakukan berkaitan dengan pembicaraan politik untuk memperoleh kemenangan.

Komunikasi politik adalah suatu bidang atau disiplin yang menelaah perilaku dan kegiatan komunikasi yang bersifat politik, mempunyai akibat politik, atau berpengaruh terhadap perilaku politik (Cangara, 2011: 29). Menurut Cangara komunikasi politik juga dapat diartikan sebagai suatu proses komunikasi yang memiliki implikasi atau konsekuensi terhadap aktivitas politik. Komunikasi politik, dengan demikian adalah upaya sekelompok manusia yang mempunyai orientasi, pemikiran politik atau ideologi tertentu dalam rangka menguasai atau memperoleh kekuasaan.

Dengan demikian, untuk mencapai tujuan politik tersebut tim pemenangan harus memiliki strategi komunikasi politik guna membentuk pencitraan positif kandidat calon agar dapat bersaing dengan kandidat calon lain. Strategi merupakan konsep awal dalam perencanaan yang disusun oleh tim pemenangan dalam menghadapi Pilkada yang bertujuan untuk mencapai kemenangan atas sasaran yang ditentukan dalam Pilkada. Dalam hal ini, sasaran yang ingin dicapai oleh tim pemenangan adalah target dukungan pemilihan yang diwujudkan dalam pemberian suara kepada kandidat calon yang diusung.

Dalam pelaksanaan Pilkada di masa pandemi covid-19, daerah Provinsi Jambi sendiri terdapat tiga kandidat calon kepala daerah yaitu (1) Drs. H. Cek Endra-Hj. Ratu Munawaroh (2) Dr. Drs. H. Fachrori Umar, M. Hum-Drs. H. Syafril Nursal, S.H., M.H. (3) Dr. H. Al Haris, S. Sos., M.H.-Drs. H. Abdullah Sani, M.Pd.I. Dengan perolehan suara sebanyak 37,4\% diperoleh oleh pasangan Drs. H. Cek Endra dan Hj. Ratu Munawaroh, 
kemudian perolehan suara sebanyak 24,3\% diperoleh oleh pasangan Dr. Drs. H. Fachrori Umar, M. Hum dan Drs. H. Syafril Nursal, S.H., M.H., dan perolehan suara sebanyak 38,3\% diperoleh oleh pasangan Dr. H. Al Haris, S. Sos., M.H. dan Drs. H. Abdullah Sani, M.Pd.I., dengan gambar sebagai berikut:

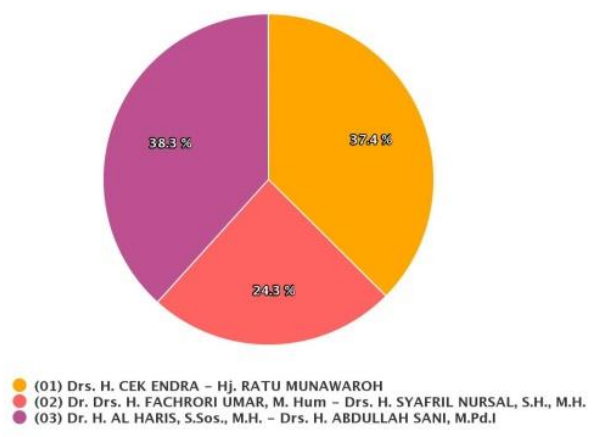

Sumber: Data dari KPU Pilkada 2020

\section{Gambar 1. Hasil Hitung Suara Pemilihan Gubernur dan Wakil Gubernur Jambi 2020}

Dari data masuk di Provinsi Jambi sebanyak 11 Kabupaten/ Kota dalam Pilkada Serentak 2020 didapatkan hasil rekapitulasi data di Kabupaten/ Kota Provinsi Jambi sebagai berikut:

Tabel 1. Hitung Suara Pemilihan Gubernur dan Wakil Gubernur Jambi 2020

\begin{tabular}{|c|c|c|c|c|c|}
\hline No. & \multicolumn{2}{|c|}{ Kabupaten/ Kota } & (01) & $(02)$ & (03) \\
\hline 1. & Kerinci & $100 \%$ & 29.717 & 50.330 & 26.909 \\
\hline 2. & Merangin & $100 \%$ & 34.443 & 16.122 & 116.100 \\
\hline 3. & Sarolangun & $100 \%$ & 82.902 & 9.556 & 37.027 \\
\hline 4. & Batanghari & $100 \%$ & 63.045 & 30.555 & 58.249 \\
\hline 5. & Muaro Jambi & $100 \%$ & 62.748 & 27.746 & 65.008 \\
\hline 6. & Tanjung Jabung Barat & $100 \%$ & 69.117 & 31.934 & 45.929 \\
\hline 7. & Tanjung Jabung Timur & $100 \%$ & 53.401 & 24.862 & 45.660 \\
\hline 8. & Bungo & $100 \%$ & 52.339 & 78.927 & 31.313 \\
\hline 9. & Tebo & $100 \%$ & 54.519 & 37.224 & 41.342 \\
\hline 10. & Kota Jambi & $100 \%$ & 74.407 & 38.421 & 126.334 \\
\hline 11. & Kota Sungai Penuh & $100 \%$ & 11.280 & 35.957 & 6.862 \\
\hline & Jumlah & & 587.918 & 381.634 & 600.733 \\
\hline
\end{tabular}

Sumber: Data diolah dari KPU Pilkada 2020

Keterangan:

(01) Drs. H. Cek Endra-Hj. Ratu Munawaroh

(02) Dr. Drs. H. Fachrori Umar, M. Hum-Drs. H. Syafril Nursal, S.H., M.H.

(03) Dr. H. Al Haris, S. Sos., M.H.-Drs. H. Abdullah Sani, M.Pd.I.

Berdasarkan tabel 1.1 tersebut, dapat diketahui jumlah keseluruhan hasil perhitungan suara pemilihan Gubernur dan Wakil Gubernur Jambi 2020 yang dikeluarkan oleh KPU pada tanggal 23 Desember 2020 dan hasil Pemungutan Suara Ulang (PSU) pada tanggal 28 Mei 2021, diketahui bahwa dalam perolehan suara di Provinsi Jambi pasangan No. Urut 03 
unggul dengan jumlah akhir adalah 600.733 kemudian disusul oleh pasangan No. Urut 01 sejumlah 587.918 dan pasangan No. Urut 02 sejumlah 381.634. Hal ini menunjukkan bahwa pasangan No. Urut 02 memperoleh dukungan suara terendah di Provinsi Jambi terutama di Kabupaten Sarolangun memperoleh suara hanya sebanyak 9.556 suara.

Dari tiap pasangan calon gubernur dan wakil gubernur ini, memiliki keunggulan masing-masing dengan visi, misi dan program kerja yang ditawarkan kepada masyarakat. Hal ini tentu bertujuan untuk memperoleh simpati dan dukungan dari masyarakat. Dalam penyampaian visi dan misi, pasangan calon kepala daerah dan setiap tim sukses atau tim pemenangan harus sangat menguasai visi dan misi serta program kerja pasangan calon yang didukung agar dapat disampaikan kepada masyarakat. Kegiatan ini merupakan bagian dari proses komunikasi politik yang dijalankan masyarakat.

Strategi komunikasi politik merupakan seluruh keputusan kondisional tentang tindakan yang akan dijalankan yang mendasar dari sasaran dan direncanakan guna mencapai tujuan politik (Anwar Arifin, 2011: 235). Perencanaan komunikasi politik berkaitan dengan produk politik yang akan dibawakan, pesan politik yang akan disampaikan serta citra yang akan dimunculkan. Setiap pasangan calon masing-masing tentu mempunyai tim sukses atau tim kemenangan guna membantu dalam menjalankan perencanaan strategi komunikasi politik yang dirancang.

Strategi komunikasi politik yang digunakan masing-masing pasangan calon pasti mempunyai cara tersendiri yang berbeda untuk memperoleh dukungan dan kemenangan dari masyarakat. Dalam rekapitulasi hasil perhitungan suara pemilihan Gubernur dan Wakil Gubernur Jambi 2020, diketahui bahwa dari tiga pasangan calon kandidat, pasangan calon nomor urut 02 yaitu Dr. Drs. H. Fachrori Umar, M. Hum dan Drs. H. Syafril Nursal, S.H., M.H., cenderung memperoleh suara terendah dari pasangan calon lainnya.

Hal tersebut menarik perhatian, dikarenakan calon Gubernur nomor urut 02 yaitu Dr. Drs. H. Fachrori Umar, M. Hum., pernah menjabat sebagai Wakil Gubernur Jambi dua periode yakni pada tahun 2010-2015 dan 2016-2018 kemudian menjadi Pelaksana Tugas Gubernur Jambi periode 2018-2019 dan sekarang berstatus sebagai petahana atau incumbent dalam mancalonkan diri di Pilgub Pilkada Jambi 2020. Sedangkan calon Wakil Gubernur nomor urut 02 yaitu Drs. H. Syafril Nursal, S.H., M.H., sebagai seorang Purnawirawan yang menjabat sebagai Kepala Kepolisian Daerah Sulawesi Tengah periode 2019-2020 dan menjalankan masa dinas militer sebagai Inspektur Jenderal Polisi dari tahun 1986-2020. 
Hal tersebut menunjukkan bahwa pasangan calon nomor urut 02 memiliki sumber daya dan keunggulan sendiri bagi kandidat incumbent seperti popularitas, citra, penguasaan opini di masyarakat serta penguasaan opini yang ada di media massa, dan persiapan financial, rekrutmen tim sukses, strategi pemenangan, pemahaman karakteristik masyarakat pemilih serta memiliki pengalaman untuk bertarung dalam dunia politik dengan mempunyai visi dan misi serta program kerja yang ditawarkan, tetapi kemudian memperoleh suara terendah pada Pemilihan Gubernur dan Wakil Gubernur Jambi tahun 2020. Tentunya ada masalah yang terjadi, sehingga hasil yang diperoleh belum mencapai tujuan dari strategi komunikasi politik yang dirancangkan oleh tim pemenangan FachroriSyafril pada Pilkada Serentak 2020 di Provinsi Jambi.

Komunikasi politik berlangsung dalam suatu proses penyampaian pesan-pesan tertentu yang berasal dari sumber, selaku pihak yang memprakarsai komunikasi, kepada khalayak dengan menggunakan media tertentu untuk mencapai suatu tujuan tertentu. Seperti halnya dengan disiplin komunikasi lainnya, maka komunikasi politik juga terdiri atas berbagai unsur, yaitu:

1. Komunikator dalam komunikasi politik, yaitu pihak yang memprakarsai dan mengarahkan suatu tindakan komunikasi. Seperti dalam peristiwa komunikasi pada umumnya, komunikator dalam komunikasi politik dapat dibedakan dalam wujud individu, lembaga, organisasi, ataupun kelompok.

2. Pesan dalam komunikasi politik, yaitu sesuatu yang disampaikan pengirim kepada penerima. Pesan dapat disampaikan dengan cara tatap muka atau melalui media komunikasi. Isinya dapat berupa informasi terkait politik, pidato politik, berita, isu-isu politik atau propaganda.

3. Media atau saluran komunikasi politik, yakni setiap pihak atau unsur yang memungkinkan sampainya pesan-pesan politik. Media yang dimaksud adalah alat yang digunakan untuk memindahkan pesan dari sumber kepada penerima. Misalnya, media cetak, media elektronik, media format kecil, media luar ruang dan segala sesuatu yang biasa digunakan untuk membangun citra.

4. Penerima atau sasaran target politik merupakan anggota masyarakat yang diharapkan dapat memberi dukungan dalam bentuk pemberian suara kepada partai atau kandidat dalam pemilihan umum.

5. Pengaruh atau efek komunikasi politik, secara umum komunikasi politik dipandang sebagai proses. Komunikasi politik merupakan kegiatan yang terus-menerus berlangsung. Artinya, apa yang terjadi sekarang sebenarnya merupakan kelanjutan dari 
apa yang terjadi diwaktu yang akan datang. Efek komunikasi politik yang diharapkan adalah terciptanya pemahaman terhadap sistem pemerintahan dan partai-partai politik, di mana nuansanya akan bermuara pada pemberian suara dalam pemilihan umum (Cangara, 2011: 31).

Strategi komunikasi politik adalah keseluruhan keputusan kondisional tentang tindakan yang akan dijalankan saat ini, guna mencapai tujuan politik pada masa depan. Strategi komunikasi politik menurut Anwar Arifin sebagai berikut:

a. Ketokohan dan Kelembagaan

Langkah pertama dalam strategi komunikasi politik, ialah merawat ketokohan dan kelembagaan. Artinya, ketokohan seorang politikus dan kemantapan lembaga politiknya dalam masyarakat akan memiliki pengaruh tersendiri dalam komunikasi politik. Selain itu, diperlukan kemampuan dan dukungan lembaga dalam menyusun pesan politik, menetapkan metode, dan memilih media politik yang tepat.

1. Merawat Ketokohan

Menurut Anwar Arifin (2011: 236-237) beberapa hasil studi menunjukkan bahwa pemberi suara dalam pemilihan umum cenderung menjatuhkan pilihannya kepada pahlawan politik, yaitu kandidat yang sesuai dengan citra jabatan ideal baginya. Citra jabatan ideal yang dimaksud itu ialah politikus yang memiliki ketokohan, karena mempunyai sifat-sifat utama seperti kecakapan, kedewasaan, keberanian dan sebagainya. Dengan demikian pahlawan politik memiliki daya tarik tersendiri, yang dalam proses komunikasi politik sangat penting untuk memengaruhi khalayak terutama calon pemilih.

2. Memantapkan Kelembagaan

Menurut Anwar Arifin (2011: 241) ketokohan seorang politikus, aktivis atau profesional akan meningkat jika ia didukung oleh lembaga yang ternama, atau berkiprah dalam lembaga tersebut. Jadi, lembaga merupakan sebuah kekuatan yang besar dalam membantu proses komunikasi politik yang efektif. Lembaga yang dimaksud adalah wadah kerjasama beberapa orang untuk mencapai tujuan bersama. Dalam dunia politik, lembaga itu dapat berupa partai politik, parlemen, dan pemerintahan atau birokrasi.

b. Menciptakan Kebersamaan

Menurut Anwar Arifin (2011: 243) suasana homofili yang harus diciptakan antara politikus dan khalayak adalah persamaan bahasa (simbol komunikasi), persamaan busana, persamaan kepentingan dengan khalayak, terutama mengenai pesan politik, 
metode, dan media politik. Namun, yang sangat penting adalah siapa tokoh yang melakukan komunikasi khalayak. Artinya, politikus atau aktivis telah memiliki persamaan dengan khalayaknya.

1. Memahami Khalayak

Menurut ahli Laswell terdapat tiga bentuk pengaruh kelompok yang bisa dijadikan sebagai faktor dalam memahami khalayak, yaitu attention area, public area, dan sentiment area. Attention area merupakan bidang dimana perhatian individu identik dengan masyarakat. Perhatian ini dipengaruhi oleh pengalaman sendiri, tetapi yang menjadi pokok persoalan adalah bagaimana seseorang mengambil tindakan terhadap suatu persoalan yang sama atau berbeda dengan tindakan masyarakat. Kemudian public area, yaitu bidang yang memberi pengaruh terhadap seseorang karena adanya keterikatan psikologis yang amat kuat antara kelompok dan individu. Selanjutnya sentiment area adalah sesuatu yang dalam diri seseorang terdapat ikatan-ikatan yang sangat sukar untuk dijelaskan dan hanya dirasakan kebenarannya saja.

2. Menyusun Pesan Persuasif

Menurut Anwar Arifin (2011: 248) syarat-syarat yang perlu diperhatikan dalam menyusun pesan politik yang bersifat persuasif, adalah menentukan tema dan materi yang sesuai dengan kondisi dan situasi khalayak. Syarat utama dalam memengaruhi khalayak dari pesan tersebut ialah harus mampu membangkitkan perhatian, selain keinginan khalayak untuk menyaksikan politikus yang akan menyajikan pesan-pesan politik tersebut.

3. Menetapkan Metode

Menurut Anwar Arifin (2011: 252) momentum penting yang harus dilewati yang hasilnya dapat diukur adalah pemilihan umum. Suara yang diraih dalam pemilihan umum akan merupakan hasil konkret dari keseluruhan kerja politik termasuk komunikasi politik, khususnya yang berkaitan dengan metode yang digunakan.

4. Memilah dan Memilih Media

Menurut Anwar Arifin (2011: 257) seluruh media dapat digunakan dalam komunikasi politik, karena tujuannya adalah untuk membentuk dan membina pendapat umum, serta mempengaruhi pemberi suara dalam pemilihan umum. Untuk komunikasi jarak dekat atau tatap muka tentu media tidak diperlukan. Khusus untuk berkomunikasi jarak jauh dengan orang banyak maka diperlukan media massa atau media interaktif (internet). 
c. Membangun Konsensus

Langkah strategis ketiga yang harus dilakukan untuk mencapai tujuan komunikasi politik, yaitu membangun konsensus baik antara para politikus dan dalam satu partai politik maupun antara para politikus dari partai yang berbeda.

1. Seni Berkompromi

Menurut Anwar Arifin (2011: 264) dalam proses lobi antara politikus yang berbeda pendapat, harus dibuka berbagai kemungkinan, sebab yang dicari adalah konsensus politik atau solusi politik dari adanya konflik politik. Dalam hal ini, diperlukan kiat atau seni tersendiri.

2. Bersedia Membuka Diri

Menurut Anwar Arifin (2011: 265) para politikus yang akan melakukan lobi untuk mencari solusi dengan membangun konsensus harus memulai dengan kesediaan membuka diri. Para pelobi harus siap membuka diri, yaitu menerima pengalaman baru atau gagasan baru, sesuai dengan konsep diri yang ada pada masing-masing politikus yang berbeda pendapat.

Dalam menerapkan strategi komunikasi politik pasangan Fachrori-Syafril dalam Pilkada Serentak 2020 di Provinsi Jambi tentu menjalankan proses penyampaian pesanpesan untuk mempengaruhi khalayak dengan menggunakan media tertentu untuk mencapai suatu tujuan tertentu.

Hal ini juga sejalan dengan penelitian Rosa Arista Narendra (2011) jurnal dengan judul "Strategi Komunikasi Politik Pasangan Bambang-Icek Dalam Pemilihan Umum Kepala Daerah Kabupaten Grobongan Tahun 2011”. Hasil penelitian menunjukkan bahwa pasangan Bambang-Icek merupakan pasangan incumbent yang terpilih kembali untuk periode 2011-2016. Strategi komunikasi politik yang digunakan untuk memperoleh kemenangan dalam pemilihan umum kepala daerah Kabupaten Grobogan tahun 2011 adalah dengan 1) Merawat Ketokohan yaitu dengan cara menjalankan pemerintahan secara normatif yaitu sesuai dengan aturan yang berlaku 2) Pemantapan Kelembagaan yaitu dengan cara adanya pertemuan rutin dengan kader 3) Memahami Khalayak yaitu dengan cara ikut turun langsung ke masyarakat 4) Menyusun Pesan Persuasif yaitu dengan cara menciptakan slogan 5) Menetapkan Metode yaitu dengan melakukan survei 6) Memilah dan Memilih Media yaitu dengan cara pendekatan komunikasi jarak dekat dan jarak jauh 7) Seni Berkompromi yaitu dengan cara lobi antar beda politikus 8) Bersedia Membuka Diri yaitu dengan cara open house menerima tamu di rumah. 
Dalam hal ini tim pemenangan Fachrori-Syafril juga membuat perencanaan dan pelaksanaan strategi komunikasi politik untuk memperoleh kemenangan dalam Pilkada Serentak 2020 di Provinsi Jambi, namun hasil perolehan suara yang didapatkan belum mencapai tujuan dari strategi komunikasi politik yang dirancangkan oleh tim pemenangan Fachrori-Syafril pada Pilkada Serentak 2020 di Provinsi Jambi.

Berdasarkan uraian di atas, maka penelitian ini bertujuan untuk mengetahui:

1. Strategi komunikasi politik yang digunakan oleh tim pemenangan Fachrori-Syafril.

2. Kelebihan dan kelemahan strategi komunikasi politik Fachrori-Syafril.

3. Penyebab rendahnya perolehan suara Fachrori-Syafril pada Pilkada Serentak 2020 di Provinsi Jambi.

\section{METODE PENELITIAN}

Dalam penelitian ini digunakan pendekatan kualitatif deskriptif. Sugiyono (2015: 1) metode penelitian kualitatif adalah metode penelitian yang berlandaskan pada filsafat postpositivisme, digunakan untuk meneliti pada kondisi objek alamiah, dimana peneliti adalah sebagai instrumen kunci, pengambilan sampel sumber data dilakukan secara purposive dan snowball, teknik pengumpulan dengan triangulasi, analisis data bersifat induktif/ kualitatif, dan hasil penelitian lebih menekankan makna daripada generalisasi. Tempat diadakannya penelitian ini adalah di posko tim pemenangan Provinsi dan media center pasangan calon nomor urut 02 Fachrori-Syafril dan dilaksanakan dari bulan Juni sampai dengan Juli 2021.

Teknik pengumpulan data yang digunakan dalam penelitian ini yaitu wawancara, observasi, dan dokumentasi. Wawancara digunakan untuk mendapatkan informasi maupun data kepada informan secara langsung sehingga data yang didapat lebih jelas serta mendalam. Peneliti melakukan wawancara kepada informan yang dianggap mempunyai pengetahuan terkait fokus penelitian yaitu ketua tim koordinator Kota Jambi, ketua harian tim pemenangan Fachrori-Syafril Provinsi Jambi, ketua divisi media center, serta anggota pemuda tim pemenangan Fachrori-Syafril Provinsi Jambi. Dalam penelitian ini peneliti juga melakukan wawancara kepada masyarakat dari beberapa Kabupaten/ Kota di Provinsi Jambi sebagai informan pendukung. Peneliti melakukan wawancara untuk mendapatkan data tentang strategi komunikasi politik yang digunakan oleh tim pemenangan pada Pilkada Serentak 2020.

Selain itu observasi dilakukan dengan mengamati rekapitulasi perolehan suara pada Pilkada Serentak 2020 di Provinsi Jambi serta daftar kegiatan yang berkaitan dengan 
komunikasi politik tim pemenangan Fachrori-Syafril pra Pilkada serentak 2020. Dokumen berupa rekapitulasi perhitungan suara pada Pilkada serentak tahun 2020 dari website resmi KPU Pilkada, foto-foto dokumentasi kegiatan tim pemenangan Fachrori-Syafril pada pra Pilkada serentak 2020, dan dokumentasi penelitian.

Teknik analisis data penelitian ini adalah deskriptif kualitatif yang telah diarahkan untuk menggambarkan dan menganalisa fakta dengan argumen yang tepat. Penelitian ini menggunakan uji validitas data berupa triangulasi sumber, triangulasi metode, dan triangulasi waktu. Penggunaan triangulasi ini dilakukan agar data yang diperoleh dipastikan benar dan bisa saling melengkapi apabila salah satu sumber, metode maupun waktu terdapat kekurangan.

\section{HASIL DAN PEMBAHASAN}

Berdasarkan hasil wawancara, observasi dan dokumentasi yang dilakukan peneliti dengan informan penelitian mengenai strategi komunikasi politik tim pemenangan Fachrori-Syafril pada Pilkada Serentak 2020 di Provinsi Jambi, kelemahan dan kelebihan strategi komunikasi politik yang digunakan oleh tim pemenangan Fachrori-Syafril serta penyebab rendahnya perolehan suara Fachrori-Syafril pada Pilkada Serentak 2020, dapat dijelaskan sebagai berikut:

\section{Strategi Komunikasi Politik Tim Pemenangan Fachrori-Syafril Pada Pilkada Serentak 2020 di Provinsi Jambi}

Strategi komunikasi Politik dalam menghadapi Pilkada Serentak 2020 merupakan konsep awal dalam perencanaan yang disusun oleh tim pemenangan yang bertujuan untuk mencapai kemenangan atas sasaran yang ditentukan dalam Pilkada. Dalam hal ini, sasaran yang ingin dicapai oleh tim pemenangan adalah target dukungan pemilihan yang diwujudkan dalam pemberian suara kepada pasangan calon yang diusung. Dalam hal melihat strategi komunikasi politik tim pemenangan Fachrori-Syafril pada Pilkada Serentak 2020, peneliti menggunakan teori yang dikemukakan oleh Prof. Dr. Anwar Arifin (2011: 235-265) mengenai strategi komunikasi politik sebagai berikut:

\section{a. Ketokohan dan Kelembagaan}

Langkah strategis pertama yang harus dilakukan untuk mencapai tujuan komunikasi politik yaitu untuk pencitraan politik, ialah dengan cara merawat ketokohan dan memantapkan kelembagaan. Artinya, ketokohan seorang politikus dan kemantapan lembaga politiknya dalam masyarakat akan memiliki pengaruh dalam berkomunikasi 
politik (Anwar Arifin 2011:236). Tim pemenangan Fachrori-Syafril dalam hal ini melakukan beberapa kegiatan, antara lain:

1. Membangun Citra Kandidat

Dalam menjelang Pilkada Serentak 2020 tim pemenangan Fachrori-Syafril telah mulai melancarkan strategi kampanye yang bertujuan untuk mensosialisasikan pasangan calon kepada khalayak. Dalam hal ini ialah dengan cara membangun citra dari sisi karakter ketokohan pasangan calon yaitu sosok yang agamais dan sosok yang tegas, dari latar belakang pendidikan seorang petahana yang bergelar doktor dan seorang Jendral Kepolisian yang dimiliki pasangan calon dan memperlihatkan pencapaian yang pernah dilakukan untuk Jambi sebelumnya melalui berbagai media, sehingga ketokohan pasangan calon sudah dikenal masyarakat dari masa kepemimpinan kandidat.

\section{Menciptakan Komunikasi yang Efektif dengan Tim}

Salah satu hal yang menjadi kekuatan besar dalam sebuah tim adalah terjalinnya komunikasi yang baik antara semua tim. Dalam hal ini, tim pemenangan FachroriSyafril selalu berusaha menjaga komunikasi dengan semua tim yang ada yaitu dengan cara rutin mengadakan pertemuan rapat dan selalu melakukan koordinasi dengan semua tim di daerah dari tingkat Provinsi sampai tingkat RT, berusaha memperhatikan keperluan yang dibutuhkan tim untuk melaksanakan kampanye, dengan demikian kekompakan dan rasa solidaritas antara tim selalu terjaga.

\section{b. Menciptakan Kebersamaan}

Langkah kedua yang harus dilakukan dalam menjalankan strategi komunikasi politik untuk menciptakan suasana kebersamaan antara politikus dan khalayak dengan cara memahami khalayak, menyusun pesan, metode, dan media politik (Anwar Arifin 2011:243). Tim pemenangan Fachrori-Syafril dalam hal ini melakukan beberapa kegiatan, antara lain:

\section{Agenda Door to Door}

Dalam hal ini, tim pemenangan Fachrori-Syafril juga melakukan terobosan-terobosan untuk mengomunikasikan pesan politiknya, seperti diadakannya agenda door to door ke masyarakat. Hal ini dilakukan untuk mempromosikan pasangan calon dengan menawarkan visi dan misi serta program kerja Jambi Berkah ke masyarakat, dalam hal ini tim datang langsung ke lapangan bersama kandidat untuk merangkul dan melakukan pendekatan emosional dengan masyarakat sesuai karakter dan kebutuhan dari masyarakat, salah satunya jika masyarakat ada hajatan atau ada masyarakat yang meninggal dunia, dari kandidat sendiri atau dari tim yang mewakili selalu berusaha 
untuk menghadiri. Hal tersebut dilakukan untuk mengetahui karakter dan kebutuhan yang masyarakat inginkan, sehingga mampu meyakinkan masyakarat untuk mendukung pasangan calon dan bermuara pada pemberian suara pada Pilkada Serentak 2020.

2. Kampanye Melalui Berbagai Media

Di masa kampanye menjelang Pilkada dilaksanakan, pemasangan alat peraga kampanye dan menyebarkan informasi di berbagai media merupakan cara yang menarik dalam menggencarkan proses komunikasi politik kepada masyarakat. Dalam hal ini, tim pemenangan Fachrori-Syafril memanfaatkan peran media dalam mempromosikan pasangan calon, terutama tim media center mempunyai peran handil untuk melakukan koordinasi dengan semua media, baik itu media cetak, media elektronik, media online sampai media sosial. Tim media center melakukan pemetaan isu dan membuat konten untuk menyebarkan informasi baik itu dari pasangan calon, visi dan misi serta program Jambi Berkah dalam bentuk siaran di Televisi, spanduk, brosur dan video konten. Hal tersebut dilakukan agar masyarakat dapat melihat dan terpengaruh untuk memilih pasangan calon.

\section{c. Membangun Konsensus}

Langkah strategis terakhir yang harus dilakukan dalam mencapai tujuan dari komunikasi politik ialah membangun konsensus baik antara para politikus dalam satu partai politik maupun antara politikus dari partai berbeda (Anwar Arifin, 2011:264). Tim pemenangan Fachrori-Syafril dalam hal ini melakukan beberapa kegiatan, antara lain:

1. Mengadakan Pertemuan-pertemuan Rapat Tim Pemenangan

Pertemuan-pertemuan rapat tim pemenangan dilakukan dengan tujuan selain untuk menjalin silaturahmi dan komunikasi antara tim juga untuk merancang perencanaan dan pelaksanaan di lapangan, menyatukan pendapat dari semua perbedaan yang ada, menyelesaikan permasalahan yang terjadi, menampung semua ide, gagasan, masukan, kritik dan saran untuk didiskusikan bersama dan jika itu baik untuk pemenangan maka selanjutnya akan disampaikan ke kandidat untuk dapat dipertimbangkan masukan yang ada dengan tujuan untuk dapat mensukseskan pelaksanaan kampanye yang dilakukan. Rapat ini biasanya dilakukan minimal satu kali dalam seminggu.

\section{Kelemahan dan Kelebihan Strategi Komunikasi Politik Tim Pemenangan Fachrori-Syafril Pada Pilkada Serentak 2020 di Provinsi Jambi}

Dalam melaksanakan strategi komunikasi politik dalam masa kampanye menuju Pilkada Serentak 2020, tentu terdapat kelemahan dan kelebihan dari strategi komunikasi 
politik yang dijalankan oleh tim pemenangan Fachrori-Syafril. Berikut adalah kelemahan dan kelebihan strategi komunikasi politik yang digunakan tim pemenangan Fachrori-Syafril pada Pilkada Serentak 2020 di Provinsi Jambi:

\section{a. Kelemahan Strategi Komunikasi Politik Tim Pemenangan Fachrori-Syafril Pada}

\section{Pilkada Serentak 2020 di Provinsi Jambi}

Kelemahan dari strategi komunikasi politik yang dilakukan oleh Tim Pemenangan Fachrori-Syafril adalah:

1. Keterbatasan Waktu Dalam Melakukan Kampanye

Dalam masa kampanye menjelang Pilkada dilaksanakan, tim pemenangan mengkampanyekan pasangan calon dalam kurun waktu yang singkat dan terbatas terutama untuk salah satu calon kandidat yaitu calon wakil gubernur yang bisa dikatakan adalah orang baru yang terjun ke ranah politik, dimana sebelumnya beliau merupakan seorang Jenderal Kepolisian yang bertugas di daerah Sulawesi dan baru kembali lagi ke Jambi, sehingga masyarakat belum bisa menerima dengan cepat dalam waktu yang singkat meskipun sudah dilakukan usaha yang maksimal untuk mendatangi masyarakat secara langsung ke berbagai daerah di Provinsi Jambi.

\section{Manajemen Kandidat Tidak Berjalan Maksimal}

Kelemahan lain yang dirasakan oleh tim pemenangan Fachrori-Syafril adalah manajemen kandidat yang tidak berjalan maksimal, yang dimana tidak hanya kandidat saja melainkan juga keluarga harus bekerja sama dalam koridor kemenangan, jadi jika tim keluarga dan kandidat tidak bisa diatur berjalan dalam koridor kemenangan maka akan menjadi penghambat dalam pelaksanaan strategi komunikasi politik di lapangan, karena untuk dapat merangkul masyarakat tidak hanya dari tim saja melainkan perlu kerjasama yang baik antara semua tim.

\section{Manajemen Pengelolaan Suara Tidak Berjalan}

Kelemahan selanjutnya yaitu dari manajemen pengelolaan suara yang tidak berjalan, terutama dalam hal sistem rekruitment dan pelatihan yang sebenarnya sangat penting untuk dilaksanakan kepada semua tim agar mempunyai bekal persiapan untuk bekerja di lapangan, namun tidak terlaksana dikarenakan waktu yang terlambat.

\section{Tidak Ada Orang Kepercayaan Dalam Tim untuk Mengurus Dana Kampanye}

Kelemahan selanjutnya yang dirasakan oleh tim pemenangan adalah tidak ada orang kepercayaan kandidat di dalam tim untuk mengatur urusan dana kampanye. Selama masa kampanye urusan dana yang memegang adalah keluarga dari kandidat sendiri, 
yang dimana dinilai oleh ketua tim kurang efektif karena masih terdapat keraguan dalam proses pencairan dana untuk kebutuhan kampanye.

5. Komunikasi Tidak Berjalan Baik di Akhir Masa Kampanye

Dalam sebuah tim pemenangan, komunikasi merupakan hal yang penting dalam menjalankan strategi untuk kemenangan. Namun, di masa akhir kampanye tim pemenangan merasakan komunikasi tidak berjalan dengan baik, menurut tim ada sebuah keputusan lain yang tidak dikomunikasikan dengan tim, sehingga membuat tim menjadi goyah di akhir masa kampanye.

b. Kelebihan Strategi Komunikasi Politik Tim Pemenangan Fachrori-Syafril Pada Pilkada Serentak 2020 di Provinsi Jambi

Kelebihan dari strategi komunikasi politik yang dilakukan oleh Tim Pemenangan Fachrori-Syafril adalah dari kekompakan tim dalam menjalin komunikasi yang baik dalam hal perencanaan maupun dalam pelaksanaan dilapangan.

\section{Penyebab Rendahnya Perolehan Suara Fachrori-Syafril Pada Pilkada Serentak} 2020

Hasil perolehan suara yang diperoleh pasangan calon nomor urut 02 Fachrori-Syafril pada Pilkada Serentak 2020 menghasilkan perolehan suara terendah dari pasangan calon lain yaitu dari 11 Kabupaten/ Kota di Provinsi Jambi hanya memperoleh suara sebanyak 381,634 suara. Padahal tim pemenangan Fachrori-Syafril Provinsi Jambi telah berupaya untuk dapat merebut simpati masyarakat. Beragam strategi, agenda kegiatan, dan program kerja sudah dijalankan untuk menarik simpati masyarakat agar terpanggil untuk memilih pasangan calon Fachrori-Syafril. Berikut adalah faktor-faktor yang menjadi penyebab rendahnya perolehan suara pasangan nomor urut 02 Fachrori-Syafril pada Pilkada Serentak 2020 di Provinsi Jambi:

\section{a. Faktor Kampanye yang Terbatas}

Dalam hal ini, pada masa kampanye dimanfaatkan tim pemenangan untuk mempromosikan pasangan calon kepada masyarakat tentunya dengan berbagai strategi dan memanfaatkan peran media dalam membantu mengkampanyekan. Namun, waktu kampanye yang singkat dan terbatas belum mampu memaksimalkan sosialisasi yang dilakukan, waktu yang diperlukan oleh tim masih dirasa kurang dalam melakukan sosialisasi lebih luas, terlebih masih banyak terdapat kendala di lapangan dalam melakukan tugas kampanye. 


\section{b. Orang Baru Dalam Ranah Politik}

Dalam hal ini, salah satu kandidat dari pasangan calon yaitu calon wakil gubernur Irjen. Pol. Drs. H.Syafril Nursal, S.H., M.H., adalah seorang Jenderal Kepolisian yang pernah bertugas di daerah Sulawesi, sehingga bisa dikatakan beliau merupakan orang baru yang terjun ke ranah politik untuk mencalonkan diri sebagai wakil gubernur Provinsi Jambi pada Pilkada Serentak 2020. Sehingga dalam masa kampanye beliau perlu melakukan sosialisasi dan memperkenalkan diri kepada masyarakat dengan lebih maksimal ke berbagai daerah di Provinsi Jambi, namun karena waktu yang singkat dan kurang sehingga masyarakat merasa belum bisa menerima dan mengenal dengan cepat dalam waktu yang singkat.

\section{c. Manajemen Kandidat Tidak Berjalan Maksimal}

Selanjutnya penyebab lain rendahnya perolehan suara pasangan calon nomor urut 02 Fachrori-Syafril adalah dari manajemen kandidat yang tidak berjalan maksimal, yang dimana tidak hanya kandidat saja melainkan juga keluarga harus bekerja sama dalam koridor kemenangan, jadi jika tim keluarga dan kandidat tidak bisa diatur berjalan dalam koridor kemenangan maka akan menjadi penghambat dalam pelaksanaan strategi komunikasi politik di lapangan, karena untuk dapat merangkul masyarakat tidak hanya dari tim saja melainkan perlu kerjasama yang baik antara semua tim.

\section{d. Faktor Kekecewaan dari Masyarakat}

Namun, dari beberapa faktor penyebab rendahnya perolehan suara pasangan calon nomor urut 02 Fachrori-Syafril, ada salah satu faktor yang mengakibatkan perolehan suara tidak sesuai dengan yang diharapkan yaitu dari faktor kekecewaan masyarakat terhadap calon petahana yang pada masa jabatan sebelumnya menjanjikan kepada masyarakat untuk pembangunan tetapi belum ada direalisasikan sehingga tidak cukup waktu untuk mendatangi satu persatu dan membujuk masyarakat.

\section{SIMPULAN}

Dari paparan di atas dapat ditarik kesimpulan sebagai berikut:

1. Dalam menghadapi Pilkada Serentak 2020 Provinsi Jambi, tim pemenangan pasangan calon nomor urut 02 Fachrori-Syafril melakukan beberapa strategi komunikasi politik, strategi komunikasi politik yang digunakan tim pemenangan Fachrori-Syafril untuk mempengaruhi khalayak pada Pilkada Serentak 2020, diantaranya adalah membangun citra kandidat, menciptakan komunikasi yang efektif dengan tim, agenda door to door, 
kampanye melalui berbagai media serta mengadakan pertemuan-pertemuan rapat tim pemenangan.

2. Namun beragam strategi komunikasi politik yang digunakan tim pemenangan Fachrori-Syafril pada Pilkada Serentak 2020 di Provinsi Jambi, ternyata tidak membuahkan hasil yang maksimal sesuai dengan yang diharapkan dikarenakan kelemahan-kelemahan dari strategi komunikasi politik yang dijalankan, kelemahankelemahan strategi komunikasi politik tim pemenangan Fachrori-Syafril, diantaranya keterbatasan waktu dalam melakukan kampanye, manajemen kandidat tidak berjalan maksimal, manajemen pengelolaan suara tidak berjalan, tidak ada orang kepercayaan dalam tim untuk mengurus dana kampanye, komunikasi tidak berjalan baik di akhir masa kampanye. Untuk kelebihan dari strategi komunikasi politik yang dijalankan oleh tim pemenangan Fachrori-Syafril yaitu dari kekompakan tim dalam menjalin komunikasi yang baik dalam hal perencanaan maupun dalam pelaksanaan dilapangan.

3. Tidak maksimalnya strategi komunikasi politik yang dijalankan oleh tim pemenangan Fachrori-Syafril mengakibatkan rendahnya perolehan suara pasangan nomor urut 02 pada Pilkada Serentak 2020, penyebab rendahnya perolehan suara pasangan nomor urut 02 Fachrori-Syafril diantaranya faktor kampanye yang terbatas, orang baru dalam ranah politik, manajemen kandidat tidak berjalan maksimal, serta faktor kekecewaan dari masyarakat.

\section{SARAN}

Berdasarkan hasil penelitian ini, ada beberapa hal yang peneliti sarankan kepada pihak-pihak yang terkait adalah sebagai berikut:

1. Dalam upaya melakukan kampanye ke masyarakat, hendaknya dapat lebih dimaksimalkan lagi strategi komunikasi politik yang digunakan terutama dalam hal manajemen kandidat, manajemen pengelolaan suara dan manajemen waktu.

2. Hendaknya tim pemenangan Fachrori-Syafril, melakukan strategi-strategi komunikasi politik yang lebih sesuai dengan dinamika politik di Jambi.

3. Untuk peneliti selanjutnya diharapkan untuk mempertajam lagi fokus kajian dengan meneliti kasus yang terjadi di Pilkada Serentak 2020 di Provinsi Jambi. 


\section{DAFTAR PUSTAKA}

Adeni, S, \& Harahap, MA (2018). Komunikasi Politik Dan Keterwakilan Perempuan Dalam Arena Politik. ... Komunikasi: Jurnal Ilmu Komunikasi Politik ..., jurnal.umj.ac.id, https://jurnal.umj.ac.id/index.php/perspektif/article/view/2849

Alfiyani, N (2018). Media Sosial sebagai Strategi Komunikasi Politik. Potret Pemikiran, journal.iain-manado.ac.id, manado.ac.id/index.php/PP/article/view/762

Alvin, S (2020). Strategi Komunikasi Politik Juru Bicara Wakil Presiden 2014-2019 sebagai Humas Pemerintah. Jurnal Komunikasi, journal.trunojoyo.ac.id, https://journal.trunojoyo.ac.id/komunikasi/article/view/6031

Aminah, A (2018). Peran Media Dalam Komunikasi Politik Jelang Pemilihan Umum Kepala Daerah Tahun 2017 Di Kabupaten Aceh Barat. SOURCE: Jurnal Ilmu Komunikasi, jurnal.utu.ac.id, http://www.jurnal.utu.ac.id/jsource/article/view/521

Arifin, Anwar. 2011. Komunikasi Politik Filsafat Paradigma Teori Tujuan Strategi dan Komunikasi Politik Indonesia. Yogyakarta: Graha Ilmu.

Armi, Z (2018). Strategi Komunikasi Politik Pasangan Calon Walikota Banda Aceh pada Pilkada 2017 (Studi Pada Tim Pemenangan Aminullah Usman dan Zainal Arifin)., UIN Ar-Raniry Banda Aceh

Cangara, Hafied. 2011. Komunikasi Politik Konsep Teori dan Strategi. Jakarta: PT Raja Grafindo Persada.

Chumaeson, W (2021). STRATEGI KOMUNIKASI POLITIK GKR AYU KOES INDRIYAH ANGGOTA DEWAN PERWAKILAN DAERAH (DPD RI) DAPIL JAWA TENGAH PERIODE 2014-2019 .... JURNAL EKONOMI, SOSIAL \& HUMANIORA, https://jurnalintelektiva.com/index.php/jurnal/article/view/541

CIBRO, R (2018). STRATEGI KOMUNIKASI POLITIK DALAM PEMILIHAN KEPALA DAERAH DI ACEH SINGKIL (STUDI KASUS TENTANG STRATEGI KOMUNIKASI POLITIK ..., http://repositori.umsu.ac.id/xmlui/handle/123456789/2250

Dewi, EAS (2018). Komunikasi Politik Pemerintah Kabupaten Bandung Barat dalam Menyosialisasikan Masyarakat Ekonomi ASEAN (MEA). Sosiohumaniora, journal.unpad.ac.id, http://journal.unpad.ac.id/sosiohumaniora/article/view/14630

Dhani, FW (2019). Komunikasi Politik Berbasis Politik Identitas Dalam Kampanye Pilkada. Metacommunication: Journal of Communication ..., ppjp.ulm.ac.id, https://ppjp.ulm.ac.id/journal/index.php/MC/article/view/6360

Faiza, L (2019). Strategi Komunikasi Politik Pks pada Pemilihan Umum (Pemilu) Tahun 2019 di Kota Pekanbaru. JDP (JURNAL DINAMIKA PEMERINTAHAN), jurnal.univrab.ac.id, http://jurnal.univrab.ac.id/index.php/jdp/article/view/946

Fatimah, S (2018). Kampanye sebagai Komunikasi Politik. Resolusi: Jurnal Sosial Politik, ojs.unsiq.ac.id, https://ojs.unsiq.ac.id/index.php/resolusi/article/view/154

Indiana, E (2021). ANALISIS STRATEGI KOMUNIKASI POLITIK TIM PEMENANGAN FACHRORI-SYAFRIL PADA PILKADA SERENTAK 2020 DI PROVINSI JAMBI., repository.unja.ac.id, https://repository.unja.ac.id/27312/

Jumriani, J, Sultan, I, \& Maria, J (2019). Perempuan dan Politik (Strategi Komunikasi Politik untuk Pemenangan Bupati Indah Putri Pada Pilkada Luwu Utara 2015). Jurnal Commercium: Kajian ‥, ejournal.iainpalopo.ac.id, http://ejournal.iainpalopo.ac.id/index.php/jurnalcommercium/article/view/1213

Kaslam, K, \& Sulistiani, K (2020). Strategi Komunikasi Politik Partai Gelora Sulawesi Selatan di Masa Pandemi Covid-19. Vox Populi, journal3.uin-alauddin.ac.id, https://journal3.uin-alauddin.ac.id/index.php/voxpopuli/article/view/18346 
KHAIRUNNISA, K (2021). STRATEGI KOMUNIKASI POLITIK PASLON PADA KAMPANYE DI MASA PANDEMIC COVID-19 (Studi Kasus Pada Paslon Pemenang Pilkada Kabupaten Sumbawa ...., eprints.unram.ac.id, http://eprints.unram.ac.id/id/eprint/26390

Kusuma, YP (2018). Mengubah Wajah Parlemen Indonesia Melalui Strategi Pencitraan Positif Para Aktor Politik: Kajian Komunikasi Politik. Nyimak: Journal of Communication, http://jurnal.umt.ac.id/index.php/nyimak/article/view/479

Leman, R (2018). STRATEGI KOMUNIKASI POLITIK TIM SUKSES DALAM PEMILIHAN KEPALA DESA TEGALGONDO 2017 (Studi pada Tim Sukses Pemenangan Nur Mahmud dalam ..., eprints.umm.ac.id, https://eprints.umm.ac.id/43273/

Masduki, A, \& Widyatama, R (2018). Efektifitas Strategi Komunikasi Politik Elit Muhammadiyah DIY dalam Pemenangan Pemilu DPD-RI Tahun 2014. Communicare: Journal of ..., journal.lspr.edu, http://journal.lspr.edu/index.php/communicare/article/view/40

Moneter, BAH, \& Susanto, EH (2020). Strategi Komunikasi Politik Partai Baru (Studi Kasus Perolehan Suara Partai Solidaritas Indonesia di DPRD DKI Jakarta Pada Pemilu 2019). Koneksi, journal.untar.ac.id, http://journal.untar.ac.id/index.php/koneksi/article/view/6508

Narendra, Rosa Arista. 2011. Strategi Komunikasi Politik Pasangan Bambang-Icek Dalam Pemilihan Umum Kepala Daerah Kabupaten Grobogan Tahun 2011.

Njoko, V (2018). Strategi Komunikasi Politik Bupati Purwakarta Dedi Mulyadi Dalam Mensosialisasikan Program Pendidikan Berkarakter. Jurnal e-Komunikasi, publication.petra.ac.id, komunikasi/article/view/8237

Fathurrazi (2018). STRATEGI KOMUNIKASI POLITIK PEMENANGAN CALON LEGISLATIF. PARTAI DEMOKRASI INDONESIA PERJUANGAN (PDIP) DI DESA SUNGAI ASAM .... ASPIRASI-Jurnal Ilmu Politik, fisipuntan.org, https://fisipuntan.org/jurnal/index.php/aspirasi/article/view/2303

Noerilhamsyah, I (2019). STRATEGI KOMUNIKASI POLITIK PADA PEMILU 2019 DI KOTA BANDUNG., repository.unpas.ac.id, http://repository.unpas.ac.id/46415/

Nur, E (2019). STRATEGI KOMUNIKASI TIM SUKSES PADA KAMPANYE POLITIK UNTUK MEMENANGKAN CALON LEGISLATIF MAKASSAR. Diakom: Jurnal Media dan Komunikasi, jurnaldiakom.kominfo.go.id, http://jurnaldiakom.kominfo.go.id/index.php/mediakom/article/view/33

Nursal, $\quad$ Syafril. $2021 . \quad$ Biodata $\quad$ Syafril Nursal di https://id.m.wikipedia.org/wiki/Syafril_Nursal (Diacces 7 Juni 2021)

Oktarina, S, \& Sarwoprasodjo, S (2018). Strategi Komunikasi Politik Opinion Leader Dalam Difusi Program Pembangunan Dan Pengembangan Lembaga Lokal Di Pedesaan (Opinion Leader Political .... Metacommunication: Journal of ..., academia.edu, https://www.academia.edu/download/58687489/4687-9575-1-SM.pdf

Panuju, R (2018). Komunikasi politik jokowi: antara pencitraan dan jejaring politik. KOMUNIKATIF, jurnal.wima.ac.id, http://jurnal.wima.ac.id/index.php/KOMUNIKATIF/article/view/1709

Pilkada Serentak. 2020. Data Hasil Perhitungan Suara Gubernur dan Wakil Gubernur Provinsi Jambi 2020 di https://pilkada2020.kpu.go.id/ (Diacces 18 Juni 2021)

Putra, HR (2021). Strategi Komunikasi Politik Partai Aceh Dalam Menarik Simpati Masyarakat. Persepsi: Communication Journal, jurnal.umsu.ac.id, http://jurnal.umsu.ac.id/index.php/PERSEPSI/article/view/8039 
Putri, DNK (2020). STRATEGI KOMUNIKASI POLITIK PADMASARI MESTIKAJATI DARI PARTAI GOLONGAN KARYA (STUDI KASUS PEMENANGAN DAPIL 5 DI BLORA)., lib.unnes.ac.id, http://lib.unnes.ac.id/id/eprint/42374

Putri, NWE (2020). Perempuan Hindu Dalam Kajian Komunikasi Politik Dan Gender. Communicare, jurnal.stahnmpukuturan.ac.id, http://jurnal.stahnmpukuturan.ac.id/index.php/communicare/article/view/756/0

Rani, S (2019). Dinamika Komunikasi Politik Dalam Pilkada Di Indonesia. Alhadharah: Jurnal Ilmu Dakwah, jurnal.uin-antasari.ac.id, http://jurnal.uinantasari.ac.id/index.php/alhadharah/article/view/2376

Saputra, WB, \& Aminulloh, A (2019). Strategi Komunikasi Politik Pasangan DewantiPunjul Pada Pilkada Kota Batu Tahun 2017. ... : Jurnal Ilmu Sosial dan Ilmu Politik, publikasi.unitri.ac.id, https://publikasi.unitri.ac.id/index.php/fisip/article/view/1467

Setiawan, DE Strategi Marketing Komunikasi Politik Pasangan Wahidin Halim-Andika Hazrumy pada Pemenangan Pilkada Provinsi Banten 2017. repository.uinjkt.ac.id, http://repository.uinjkt.ac.id/dspace/handle/123456789/41385

Suryana, C (2021). Politik sebagai Dakwah: Komunikasi Politik Partai Keadilan Sejahtera (PKS). Communicatus: Jurnal Ilmu Komunikasi, digilib.uinsgd.ac.id, http://digilib.uinsgd.ac.id/41406/

Susilo, ME, \& Nisa, NL (2019). Strategi Komunikasi Politisi Perempuan. Jurnal Ilmu Komunikasi,

103.23.20.161, http://103.23.20.161/index.php/komunikasi/article/viewFile/2682/2247

Sugiyono. 2015. Memahami Penelitian Kualitatif. Bandung: Alfabeta.

Suratno, S, Irwansyah, I, Ernungtyas, NF, \& ... (2020). Pemanfataan Media Sosial Facebook Sebagai Strategi Komunikasi Politik. ... Jurnal Ilmu Komunikasi, core.ac.uk, https://core.ac.uk/download/pdf/328027602.pdf

Tazri, M (2019). Politik Hujat dalam Sistem Komunikasi Politik Indonesia (Studi Fenomenologi Cebong-Kampret). Jurnal Communiverse, core.ac.uk, https://core.ac.uk/download/pdf/287316806.pdf

Taufik, M (2019). STRATEGI KOMUNIKASI POLITIK DEWAN PENGURUS WILAYAH PARTAI KEBANGKITAN BANGSA PROVINSI RIAU DALAM MENGEMBANGKAN PARTAI., repository.uin-suska.ac.id, http://repository.uinsuska.ac.id/21590/

Tosepu, YA (2018). Media Baru Dalam Komunikasi Politik (Komunikasi Politik di Dunia Virtual). Surabaya. CV Jakad, academia.edu, https://www.academia.edu/download/57555600/Media_Baru_dalam_Komunikasi_P olitik.pdf

Umar, Fachrori. 2021 Biodata Fachrori Umar di https://id.m.wikipedia.org/wiki/Fachrori_Umar (Diacces 7 Juni 2021)

Umar, U (2021). STRATEGI KOMUNIKASI POLITIK CALON LEGISLATIF PEREMPUAN KOTA MAKASSAR DALAM MEMENANGKAN PEMILIHAN UMUM LEGISLATIF TAHUN 2019. Journal of Communication Sciences (JCoS), journal-uim-makassar.ac.id, makassar.ac.id/index.php/JCoS/article/view/645

Yati, H, \& Thasimmim, SN (2019). STRATEGI KOMUNIKASI POLITIK PARTAI GOLKAR DALAM MEMENANGKAN PEMLU LEGISLATIF DPRD KABUPATEN KARIMUN PERIODE 2019-2024. JURNAL ..., ejurnal.universitaskarimun.ac.id, http://ejurnal.universitaskarimun.ac.id/index.php/ILKOM/article/view/25 
Zahrotunnimah, Z, Yunus, NR, \& ... (2018). Rekonstruksi Teori Komunikasi Politik Dalam Membangun Persepsi Publik. STAATSRECHT ..., journal.uinjkt.ac.id, http://journal.uinjkt.ac.id/index.php/staatsrech/article/view/11186

Zainal, AG (2018). Strategi Komunikasi Politik Pemerintahan Daerah Dalam Meningkatkan Partisipasi Masyarakat Pedesaan. MetaCommunication; Journal Of ..., repository.lppm.unila.ac.id, http://repository.lppm.unila.ac.id/22989/

Zulaiha, A (2019). Strategi Komunikasi Politik Pasangan Calon Gubernur Sulawesi Selatan H. Ichsan Yasin Limpo Sh. Mh dan Ir. HA Mudzakkar MhDi Kabupaten Pangkajene dan ...., repositori.uin-alauddin.ac.id, http://repositori.uinalauddin.ac.id/18467/ 